\title{
DAMPAK IMPLEMENTASI XBRL TERHADAP RISIKO INFORMASI
}

\author{
Yuna Adhi Pamungkas ${ }^{1}$, Ari Budi Kristanto ${ }^{2}$ \\ Universitas Kristen Satya Wacana ${ }^{1,2}$ \\ Jalan Dipinegoro 52-60, Salatiga 50711, Indonesia
}

\begin{abstract}
This study aims to determine the impact of the implementation of XBRL on information risk for corporate financial reporting. The population in this study were all manufacturing companies listed on the IDX from 2012 to 2017. The samples in this study were obtained by purposive sampling method with the criteria (1) Manufacturing companies listed on the IDX in 2012 to 2017 (2) Having complete research data. The sample used in this study amounted to 84 companies registered in IDX in 2012 to 2017. Data analysis technique used multiple regression analysis to see the effect of XBRL implementation on information risk with company size and leverage as control variables. The results of this study indicate that the implementation of XBRL and firm size have a negative effect on information risk; and leverage has a positive effect on information risk. Financial reports that use XBRL will reduce information risk so it can help stakeholders to make a good quality business decisions.

Keywords: eXtensible Business Reporting Language; Information Risk; Financial Reporting; Information Quality
\end{abstract}

\begin{abstract}
ABSTRAK
Penelitian ini bertujuan untuk mengetahui dampak implementasi eXtensible Business Reporting Language (XBRL) terhadap risiko informasi pada pelaporan keuangan perusahaan. Populasi dalam penelitian ini adalah seluruh perusahaan manufaktur yang terdaftar dalam Bursa Efek Indonesia (BEI) tahun 2012 sampai 2017. Sampel dalam penelitian ini diperoleh dengan metode purposive sampling menggunakan kriteria (1) Perusahaan manufaktur yang terdaftar di BEI berturut-turut selama tahun 2012 sampai 2017 (2) Memiliki data penelitian yang lengkap. Sampel yang dipakai dalam penelitian ini berjumlah 84 perusahaan yang terdaftar dala BEI tahun 2012 sampai 2017. Teknik analisis data yang digunakan yaitu analisis regresi berganda untuk melihat pengaruh implementasi XBRL pada risiko informasi dengan ukuran perusahaan dan leverage sebagai variabel kontrol. Hasil penelitian ini menunjukan bahwa implementasi XBRL dan ukuran perusahaan berpengaruh negatif terhadap risiko informasi; leverage berpengaruh positif terhadap risiko informasi. Laporan keuangan yang menggunakan XBRL akan menurunkan risiko informasi sehingga dapat membantu stakeholders membuat keputusan bisnis yang berkualitas.
\end{abstract}

Kata kunci: eXtensible Business Reporting Language; Risiko Informasi; Pelaporan Keuangan; Kualitas Informasi

\section{PENDAHULUAN}

Tang, Chen, dan Lin (2016) menyatakan nilai Overall Financial Reporting Quality Index (OFRQI) Indonesia berada dalam urutan ke tiga puluh enam dari tiga puluh delapan negara yang diteliti. OFRQI merupakan indeks kualitas pelaporan keuangan secara keseluruhan yang didapatkan dari rata-rata indeks kualitas pelaporan keuangan selama lima belas tahun. Nilai OFRQI Indonesia yang rendah menunjukan kualitas pelaporan keuangan yang rendah. Nilai OFRQI Indonesia hanya sebesar 18,09, masih berada dibawah rata-rata yaitu 30,67. Kualitas 
pelaporan keuangan yang rendah dapat mengakibatkan risiko informasi dalam pelaporan keuangan meningkat (Tohang \& Lan, 2017)

Risiko informasi berhubungan dengan transparansi informasi, asimetri informasi, efisiensi informasi dan kualitas pengungkapan informasi (Kim, Lim, \& No, 2011). Hubungan tersebut membuat risiko informasi sangat penting untuk diperhatikan oleh stakeholders dari sebuah perusahaan. Stakeholders bisa membuat keputusan yang kurang berkualitas jika menggunakan informasi yang mempunyai risiko informasi yang tinggi.

Dalam rangka mengurangi risiko informasi pada pelaporan keuangan, adopsi teknologi pelaporan informasi baru diterapkan melalui penggunaan eXtensible Business Reporting Language (XBRL) (Tohang \& Lan, 2017). Adopsi XBRL mampu meningkatkan kegunaan, efektifitas dan akurasi laporan keuangan dalam bentuk digital (XBRL, 2018). Lebih dari lima puluh negara sudah mengadopsi XBRL. Indonesia adalah salah satu negara yang sudah mengadopsi XBRL mulai tahun 2015. Adopsi XBRL di Indonesia dipelopori oleh Bursa Efek Indonesia (BEI). Alasan BEI mengadopsi XBRL adalah untuk menyempurnakan proses pengumpulan data pelaporan dari emiten, memajukan daya saing produk data yang ditawarkan oleh BEI kepada investor, institusi dan swasta, serta memperkuat keterbukaan dan keutuhan informasi di pasar modal (BEI, 2018)

Tohang dan Lan (2017) menyimpulkan bahwa adopsi XBRL dapat mengurangi risiko informasi dalam pelaporan keuangan pada beberapa sampel perusahaan di negara Kanada, Swedia dan Finlandia. Penelitian ini menggunakan sampel yang memiliki Capital Market Level yang berbeda dengan sampel penelitian sebelumnya. Capital Market Level menyatakan apakah pasar modal disuatu negara tersebut berkembang atau maju. Berdasarkan penelitian Tang et al. (2016) menyatakan bahwa Capital Market Level di Indonesia masih berkembang, sedangkan Capital Market Level di Finlandia, Denmark dan Swedia sudah maju. XBRL baru diadopsi di Indonesia pada tahun 2015. Penelitian ini perlu dilakukan untuk mengetahui dampak adopsi XBRL yang baru diterapkan di Indonesia.

Penelitian ini bertujuan untuk mengidentifikasi apakah adopsi XBRL mampu mengurangi risiko informasi dalam pelaporan informasi keuangan di Indonesia. Jumlah perusahaan sektor manufaktur yang tercatat dalam Bursa Efek Indonesia lebih banyak daripada jumlah perusahaan pada sektor lain sehingga diharapkan dapat merepresentasikan perusahaan yang terdaftar dalam BEI. Indeks Internet Financial Reporting (IFR) pelaporan keuangan di Indonesia dinilai sudah baik. Indeks IFR menunjukan nilai kualitas pelaporan keuangan yang disampaikan melalui internet pada suatu perusahaan yang dilihat dari konten, ketepatan waktu, tekonologi dan user support dari suatu perusahaan. Handayani dan Almilia (2013); Widari, Saifi, dan Nurlaily (2018) menyatakan bahwa indeks IFR perusahaan manufaktur di Indonesia sudah baik dan lebih tinggi dibandingkan dengan indeks IFR perusahaan manufaktur di Malaysia. Dengan indeks IFR yang baik, perlu diketahui secara spesifik apakah XBRL mampu meningkatkan kualitas informasi keuangan sehingga risiko informasi pada sektor yang memiliki IFR yang baik dapat berkurang. Sampel dalam penelitian ini merupakan perusahaan manufaktur yang tercatat di Bursa Efek Indonesia pada tahun 2012-2017. Hasil penelitian diharapkan dapat bermanfaat bagi stakeholders untuk menjadi evaluasi atas kualitas pelaporan informasi akuntansi dan bagi otoritas, dapat digunakan sebagai evaluasi atas adopsi XBRL di Indonesia. 


\section{TINJAUAN PUSTAKA DAN PENGEMBANGAN HIPOTESIS Teori Sinyal}

Menurut Connelly dkk (2011) teori sinyal berguna untuk mendiskripsikan perilaku ketika terdapat dua pihak (individu atau organisasi) memiliki perbedaan akses informasi. Salah satu pihak akan menjadi the sender yaitu pihak yang harus memilih bagaimana cara mengkomunikasikan informasi dan pihak lainnya menjadi the receiver yaitu pihak yang menerima dan menginterpretasi informasi. Informasi keuangan yang berkualitas akan memudahkan pengguna dalam menginterpretasi informasi keuangan. Perusahaan harus menyediakan pelaporan informasi keuangan yang berkualitas sehingga pengguna informasi keuangan dapat membuat keputusan yang berkualitas berdasarkan informasi tersebut.

\section{Risiko Informasi}

Menurut Tohang dan Lan (2017) terdapat dua prespektif dalam memaknai risiko informasi. Prespektif pertama mendefinisikan risiko informasi sebagai risiko yang berhubungan dengan keamanan teknologi informasi yang dapat mengancam informasi dan memungkinkan memberikan dampak negatif pada informasi. Prespektif kedua mendefinisikan risiko informasi sebagai potensi efek terhadap kualitas pelaporan informasi untuk pemegang saham dalam membuat keputusan yang berkualitas. Penelitian ini menggunakan prespektif kedua dari risiko informasi. Pengguna informasi keuangan perlu memperhatikan risiko informasi. Pengguna informasi keuangan dapat membuat keputusan yang kurang berkualitas jika menggunakan informasi yang memiliki risiko informasi yang tinggi dan keputusan tersebut akan memberikan dampak buruk kepada pengguna informasi.

\section{Adopsi XBRL di Indonesia}

XBRL adalah standar internasional terbuka untuk pelaporan bisnis digital, yang dikelola oleh konsorsium nirlaba berskala global untuk meningkatkan kualitas pelaporan demi kepentingan publik (XBRL, 2018). XBRL merupakan bagian dari eXtensible Markup Language (XML). XML membuat tagging untuk setiap bagian dari informasi dalam sebuah dokumen dan memungkinkan dokumen dapat diakses dan didistribusikan melalui berbagai aplikasi tanpa memasukan ulang data secara manual (Kernan, 2009). Dengan menggunakan XBRL suatu dokumen dapat dikonversi menjadi bentuk yang lain seperti HTML, PDF dan Microsoft Excel sehingga dapat memudahkan pengguna informasi untuk mengakses maupun mengolah suatu informasi.

XBRL yang mulai berkembang pada tahun 1998 diinisiasi oleh Charlie Hoffman yang saat itu berprofesi sebagai akuntan publik. Gagasan pelaporan bisnis berbasis XBRL yang dulunya bernama eXtensible Financial Reporting Markup Language (XFRML) diajukan ke High Tech Task Force dari American Institute of Certified Public Accountants (AICPA) untuk dapat diimplementasikan pada pelaporan bisnis. Dari pengajuan tersebut akhirnya pada tanggal 17 Juli 1999 AICPA bersedia untuk mendanai gagasan tersebut serta didukung oleh beberapa pihak. Pada tanggal 13 Oktober 1999, XBRL diuji gunakan pada sepuluh perusahaan dan akhirnya pada tanggal 31 Juli 2000 spesifikasi laporan keuangan berbasis XBRL di Amerika Serikat diterbitkan. Saat ini terdapat lebih dari lima puluh negara yang sudah menerapkan XBRL dalam pelaporan keuangan (XBRL, 2018). 
Indonesia merupakan salah satu negara yang sudah menerapkan XBRL dalam pelaporan keuangan. Adopsi XBRL di Indonesia diprakasai oleh Bursa Efek Indonesia (BEI). BEI (2018) mengadopsi XBRL bertujuan untuk: (1) Menyempurnakan proses pengumpulan data pelaporan emiten supaya lebih efisien, komperhensif dan dapat diandalkan informasinya; (2) Memajukan daya saing produk data yang akan BEI tawarkan pada investor, institusi maupun swasta; (3) Memperkuat keterbukaan dan keutuhan informasi pasar modal, serta meningkatkan pelayanan untuk semua konsumen informasi pasar modal.

Terdapat beberapa tahapan dalam pengadopsian XBRL. Berikut ini adalah alur kerja dari pengembangan pelaporan bisnis berbasis XBRL.

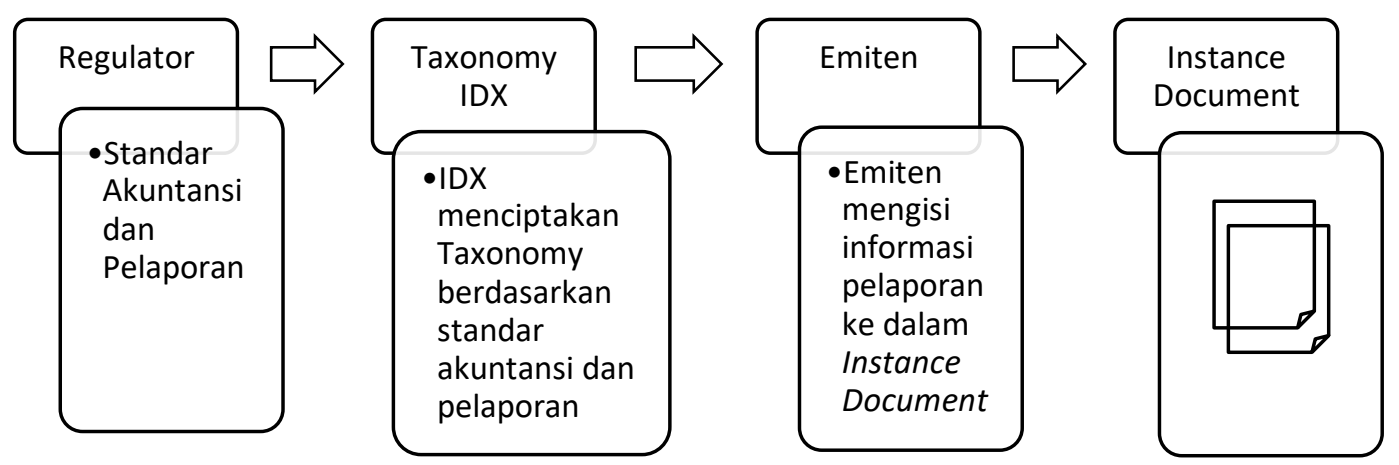

Gambar 1. Alur Kerja Pengembangan XBRL di Indonesia

Sumber : www.idx.co.id (diakses tahun 2018)

Pada tahun 2012 BEI mulai mengembangkan pelaporan keuangan berbasis XBRL dan akhirnya pada tahun 2015 BEI mengimplementasikan pelaporan keuangan berbasis XBRL. XBRL mulai diterapkan untuk berbagai pelaporan keuangan di BEI seperti laporan laba rugi, laporan perubahan ekuitas, laporan posisi keuangan serta laporan arus kas. Selain laporan keuangan, BEI juga akan mengembangkan penggunaan XBRL pada pelaporan informasi bisnis yang lainnya seperti kewajiban keterbukaan informasi dari emiten, catatan atas laporan keuangan, informasi atas tindakan korporasi emiten dan lain-lain. Dengan diterapkannya XBRL dalam pelaporan keuangan di Indonesia diharapkan mampu meningkatkan kualitas dari pelaporan keuangan di Indonesia sehingga dapat mengurangi risiko informasi.

\section{Dampak XBRL terhadap Risiko Informasi}

Risiko informasi berhubungan dengan asimetri informasi, transparansi informasi serta kualitas dari pelaporan informasi. Adopsi XBRL mampu meningkatkan tingkat pengungkapan dari laporan keuangan perusahaan, sehingga mampu mengurangi asimetri informasi dan meningkatkan transparansi serta kualitas pelaporan informasi keuangan. Dari penelitian sebelumnya diharapkan XBRL mampu mengurangi risiko informasi sehingga mampu mengurangi efek terhadap kualitas pelaporan informasi untuk pemegang saham dalam menghasilkan keputusan yang kurang berkualitas. Dengan adanya adopsi XBRL laporan keuangan menjadi lebih mudah diakses dan lebih berkualitas sehingga kemungkinan adanya risiko informasi dalam laporan keuangan menjadi menurun.

Tohang dan Lan (2017) menyatakan bahwa adopsi XBRL dapat mengurangi risiko informasi dalam pelaporan keuangan pada perusahaan di Swedia, Finlandia 
dan Denmark. Yoon, Zo, dan Ciganek (2011); Enachi (2013) menyatakan adopsi XBRL mampu mengurangi tingkat asimetri informasi pada pelaporan keuangan. Adapun Hwang, Leem, dan Moon (2008) menyatakan bahwa adopsi XBRL mampu meningkatkan transparansi informasi keuangan. Menurut Liu, Luo, dan Wang (2017) implementasi XBRL mampu meningkatkan kualitas dari laporan keuangan dengan indikator ketepatan waktu, relevansi, komparabilitas serta efisiensi dari laporan keuangan. Dari pembahasan diatas maka dirumuskan hipotesis sebagai berikut.

H1 : Perusahaan yang sudah mengadopsi XBRL memiliki tingkat risiko informasi yang rendah.

\section{METODE PENELITIAN \\ Jenis Penelitian}

Peneltian ini menggunakan jenis penelitian kuantitatif untuk meneliti dampak adopsi XBRL terhadap risiko informasi pada perusahaan manufaktur yang tercatat pada Bursa Efek Indonesia pada tahun 2012-2017.

\section{Data dan Sumber Data}

Data yang digunakan pada penelitian ini yaitu data sekunder dengan jenis data panel. Data yang digunakan adalah informasi implementasi XBRL, ukuran perusahaan, leverage, harga tutup saham dari perusahaan, harga tutup pasar dan jumlah hari trading. Data informasi implementasi XBRL, ukuran perusahaan dan leverage bersumber dari Bursa Efek Indonesia. Data harga tutup saham dari perusahaan, harga tutup pasar dan jumlah hari trading bersumber dari Yahoo Finance.

\section{Populasi dan Sampel}

Populasi pada penelitian ini yaitu perusahaan manufaktur yang tercatat di Bursa Efek Indonesia pada tahun 2012-2017. Metode purposive sampling digunakan untuk penarikan sampel dalam penelitian ini dengan kriteria : (1) Perusahaan manufaktur yang terdaftar di Bursa Efek Indonesia berturut-turut selama tahun 2012-2017 (2) Memiliki data penelitian yang lengkap.

\section{Definisi Operasional dan Pengukuran Variabel Risiko Informasi}

Risiko informasi adalah risiko dari informasi yang dapat menyebabkan pengguna informasi tersebut membuat keputusan yang kurang berkualitas (Tohang \& Lan, 2017). Menurut Kim et al. (2011) dan Sen (2009), risiko informasi dapat diukur melalui earning surprise, event return volatility, efisiensi informasi, perubahan standar deviasi atas return harian, dan perubahan standar deviasi atas analisis prediksi laba. Penelitian ini menggunakan Event Return Volatility (ERV) untuk mengukur risiko informasi (Tohang dan Lan, 2017). Menurut Bushee dan Noe (2000), ERV dipilih untuk mengindikasikan unexpected return, yang membandingkan antara return saham yang abnormal (excess) dengan reaksi pasar, menurunnya ERV dapat secara langsung mengurangi terjadinya risiko informasi dalam lingkungan pasar tertentu. ERV dapat membantu investor untuk memprediksi mengenai risiko dan kemajuan ekonomi masa depan (Tohang \& Lan, 
2017). ERV yang meningkat menunjukan risiko informasi yang tinggi. ERV didapatkan dari harga dimana investor melakukan transaksi di pasar modal. Dibawah ini merupakan rumus untuk menghitung nilai ERV.

$\begin{array}{ll}E R V_{i, t}=[S T D(\text { CLSD Stock } & \left.\left.P R C_{i, t}-\text { CLSD Market } P R C_{i, t-1}\right)\right] \times \sqrt{T D_{t}} \\ E R V_{i, t} & : \text { Event Return Volatility dari perusahaan i pada } \\ & \text { tahun } \mathrm{t} \\ & : \text { Standar deviasi tahunan dari perbedaan antara } \\ \text { STD } & \text { harga tutup saham dan harga tutup pasar } \\ \text { CLSD Stock } P R C_{i, t} & : \text { Harga tutup saham dari perusahaan i pada tahun } \mathrm{t} \\ \text { CLSD Market } P R C_{i, t-1} \quad & \text { : Harga tutup pasar dari perusahaan i pada tahun } \mathrm{t} \\ & \text { pada bulan sebelumnya } \\ T_{t} & : \text { Jumah hari trading pada tahun } \mathrm{t}\end{array}$

\section{Adopsi XBRL}

Menurut Kim et al. (2011) XBRL merupakan sebuah standar terbuka untuk struktur data yang mampu digunakan oleh pengguna dalam menyiapkan dan menyajikan laporan keuangan di dalam ataupun di luar negeri. Indikator XBRL dalam penelitian ini menggunaan dummy variabel. Dummy variabel merupakan sebuah variabel buatan yang digunakan untuk merepresentasikan sebuah atribut dengan dua atau lebih kategori atau level. Angka 0 dalam variabel ini digunakan untuk merepresentasikan tahun sebelum adopsi XBRL yaitu tahun 2012 hingga 2014 dan angka 1 untuk merepresentasikan tahun setelah adopsi XBRL yaitu tahun 2015-2017.

\section{Ukuran Perusahaan dan Leverage}

Ukuran perusahaan, dan leverage digunakan sebagai variabel kontrol dalam penelitian ini. Variabel kontrol merupakan elemen penelitian yang konstan dan tidak berubah sepanjang penelitian. Ukuran perusahaan pada penelitian ini diukur menggunakan nilai total ekuitas dari perusahaan. Leverage pada penelitian ini diukur memakai total hutang dibagi dengan total ekuitas perusahaan. Ukuran perusahaan digunakan untuk mengukur nilai buku ekuitas untuk membantu kompetisi yang agresif, sedangkan leverage memiliki hubungan yang dekat dengan risiko informasi sebagai tolak ukur tingkat derajat kemungkinan risiko keuangan dapat terjadi (Tohang, 2017).

\section{Tahapan Analisis}

Model regresi berganda merupakan teknik analisis data yang digunakan dalam penelitian ini. Penelitian ini memakai model persamaan regresi berganda yang serupa dengan penelitian (Tohang \& Lan, 2017). Untuk mengetahui dampak adopsi XBRL terhadap risiko informasi dengan ukuran perusahaan dan leverage sebagai variabel kontrol. Model regresi berganda pada penelitian ini sebelumnya dipastikan sudah lolos uji asumsi klasik yaitu normalitas, autokorelasi, heterokedastisitas dan multikolinearitas. Dibawah ini merupakan model regresi dalam penelitian ini.

$\begin{array}{cc}E R V_{i, t}=\alpha+\beta_{1} X B R L_{i, t}+\beta_{2} S I Z E_{i, t}+\beta_{3} L E V_{i, t}+\varepsilon_{i, t} \\ E R V_{i, t} & : \text { Event Return Volatility dari perusahaan i pada tahun t }\end{array}$


$\alpha$ : Konstanta

$X B R L_{i, t} \quad$ : Variabel dummy dari implementasi XBRL yang mengambil nilai 0 untuk sebelum dan 1 untuk sesudah implementasi.

$S I Z E_{i, t} \quad$ : Ukuran perusahaan dari perusahaan i pada tahun $\mathrm{t}$

$L E V_{i, t} \quad:$ Leverage dari perusahaan i pada tahun $\mathrm{t}$

Penerimaan atau penolakan hipotesis akan didasarkan pada teknik berikut ini:

Tabel 1. Panduan Penerimaan dan Penolakan Hipotesis Penerimaan Hipotesis Penolakan Hipotesis

Koefisien regresi dari variabel $X B R L\left(\beta_{1}\right)$ model Koefisien regresi dari variabel $X B R L\left(\beta_{1}\right)$ model regresi bernilai signifikan negatif. regresi bernilai signifikan positif.

\section{HASIL PENGUJIAN HIPOTESIS \\ Hasil Pengumpulan Data}

Penelitian ini bertujuan untuk mengetahui apakah implementasi XBRL dapat menurunkan tingkat risiko informasi pada pelaporan keuangan. Terdapat 81 sampel perusahaan yang didapatkan berdasarkan kriteria sampel yang sudah ditentukan sebelumnya.

Sampel perusahaan manufaktur tersebut terdiri dari tujuh belas sub sektor perusahaan manufaktur. Tabel 2 dan 3 menunjukkan jumlah dan sub sektor sampel perusahaan.

Tabel 2. Hasil Pengambilan Sampel

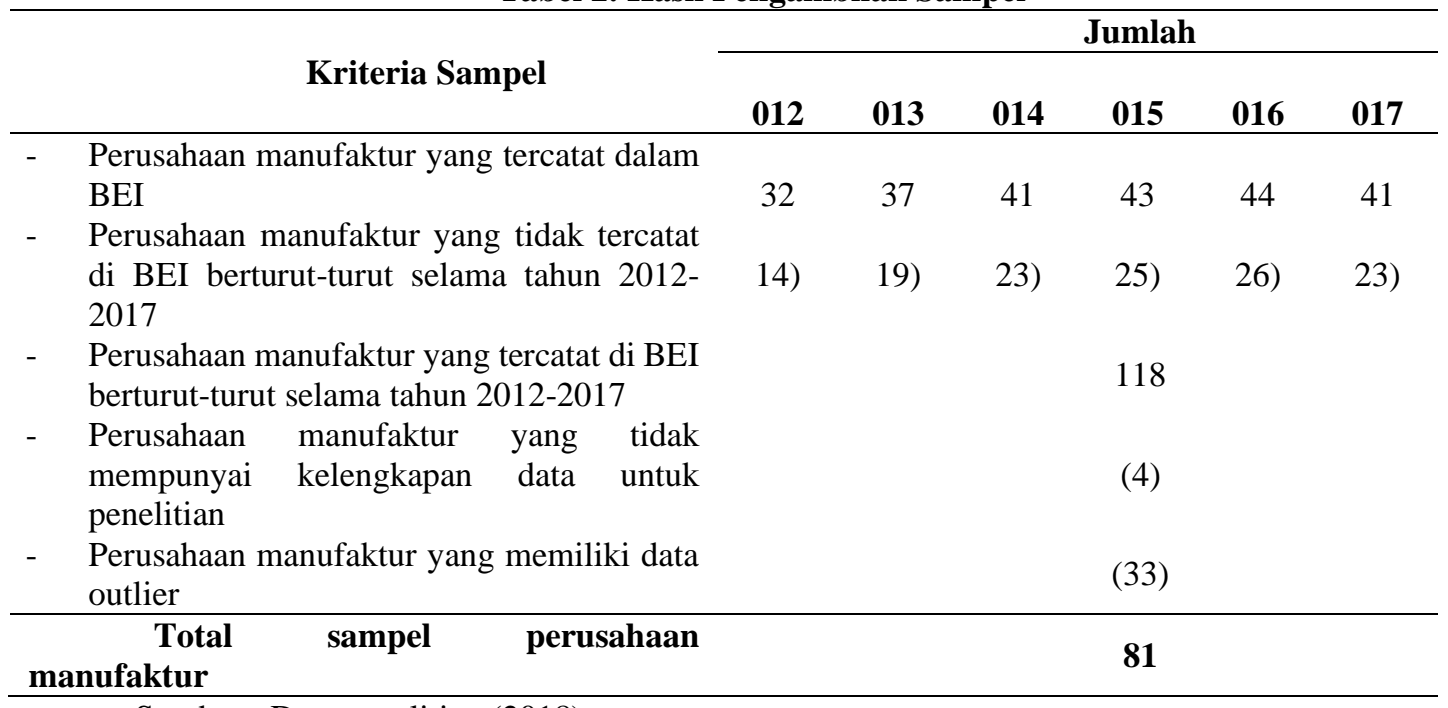

Sumber : Data penelitian (2018) 
Tabel 3. Sub Sektor Sample Penelitian

\begin{tabular}{|c|c|}
\hline Sub Sektor Perusahaan Manufaktur & Jumlah Perusahaan \\
\hline Alas Kaki & 1 \\
\hline Elektronika & 1 \\
\hline Farmasi & 5 \\
\hline Kabel & 4 \\
\hline Kayu \& Pengolahannya & 2 \\
\hline Kimia & 6 \\
\hline Kosmetik \& Barang Keperluan Rumah Tangga & 2 \\
\hline Kramik, Porselen \& Kaca & 5 \\
\hline Logam \& Sejenisnya & 7 \\
\hline Makanan \& Minuman & 10 \\
\hline Otomotif \& Komponen & 6 \\
\hline Pakan Ternak & 3 \\
\hline Plastik \& Kemasan & 6 \\
\hline Pulp \& Kertas & 7 \\
\hline Rokok & 3 \\
\hline Semen & 3 \\
\hline Tekstil \& Garment & 10 \\
\hline Total Jumlah Perusahaan & 81 \\
\hline
\end{tabular}

Sumber : Data penelitian (2018)

\section{Statistik Deskriptif}

Tabel 4 merupakan hasil dari statistik deskriptif dari setiap variabel penelitian.

Tabel 4. Statistik Deskriptif

\begin{tabular}{ccccc}
\hline Variabel & Minimum & Mean & Maximum & Std. Deviation \\
\hline ERV & 1709,36354 & 6325,629 & $101.470,21$ & 9661,81 \\
XBRL & 0 & 0,5 & 1 & 0,50052 \\
SIZE & 36.413 & $10.646 .242,85$ & $295.646 .000,00$ & $30.510 .748,94$ \\
LEV & 0,04 & 0,5255 & 3,03 & 0,40052 \\
\hline
\end{tabular}

Sumber : Data penelitian (2018)

Hasil statistik deskriptif menunjukan bahwa nilai rata-rata dari risiko informasi yang diproksikan dengan ERV adalah 6325,629 dengan standar deviasi sebesar 9661,81. Penerapan XBRL memiliki rata-rata 0,5 dengan standar deviasi sebesar 0,50050. Ukuran perusahaan (SIZE) yang diukur menggunakan total aset memiliki rata-rata Rp10.646.242.850.000,00 dengan standar deviasi 30.510.748,94. Nilai standar deviasi dari ukuran perusahaan menunjukan perusahaan dalam penelitian ini memiliki ukuran peusahaan yang bervariasi. Hal ini juga dapat dilihat dari perbandingan ukuran perusahaan terkecil dan terbesar yaitu sebesar Rp36.413.000.000,00 dan Rp295.646.000.000.000,00. Leverage yang didapatkan dari hasil pembagian total liabilitas dan total aset memiliki rata-rata 0,5255 dengan standar deviasi 0,40052. Dilihat dari nilai minimum dan maximum leverage menunjukan bahwa terdapat perusahaan yang memiliki kemampuan yang tinggi untuk memenuhi kewajibannya, tetapi ada juga yang memiliki tingkat kemampuan yang rendah untuk memenuhi kewajibannya. 


\section{Uji Asumsi Klasik}

Persamaan regresi dalam penelitian ini lolos uji asumsi klasik. Penelitian ini menggunakan analisis grafik Normal P-P Plot of Regression Standardized Residual untuk melihat normalitas data. Jika persebaran titik data berada pada sekitar sumbu diagonal dan mengikuti garis diagonal, maka model regresi penelitian ini memenuhi asumsi normalitas (Juliandi, 2013; Santoso, 2011). Pada grafik Normal P-P Plot of Regression Standardized Residual persamaan penelitian ini menunjukan bahwa persebaran titik data penelitian ini berada di sekitar garis diagonal dan mengikuti arah garis diagonal, sehingga persamaan regresi penelitian ini berdistribusi normal dan memenuhi asumsi normalitas.

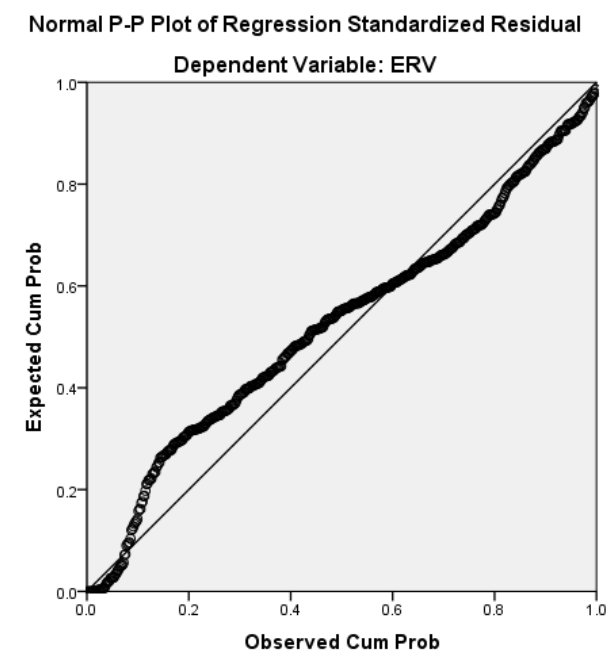

Gambar 2. Hasil Uji Normalitas

Penelitian ini menggunakan pengujian Durbin-Watson (DW) untuk mengetahui apakah terdapat autokorelasi dalam data penelitian ini. Jika nilai DW lebih besar dari nilai dU dan lebih kecil dari nilai 4-dU maka tidak terdapat autokorelasi, sehingga lolos dari uji autokorelasi. Nilai DW dalam penelitian ini adalah 1,912. Nilai dU dan 4-dU dalam penelitian ini adalah 1,863485 dan 2,161341 sehingga data penelitian ini tidak terdapat autokorelasi dan lolos dari uji autokorelasi.

Tabel 5. Hasil Uji Autokorelasi

\begin{tabular}{cccccc}
\hline $\mathbf{d L}$ & $\mathbf{d U}$ & 4-dU & 4-dL & DW & Kesimpulan \\
\hline 1,838659 & 1,863485 & 2,161341 & 2,136515 & 1,912 & Lolos \\
\hline
\end{tabular}

Pengujian heteroskedastisitas pada penelitian ini memakai analisis grafik scatterplot dari persamaan regresi. Jika persebaran titik data dalam grafik scatterplot berada diatas dan dibawah angka nol pada sumbu $\mathrm{Y}$ dan tidak membentuk pola yang jelas maka tidak terjadi heteroskedastisitas (Santoso, 2011). Grafik scatterplot persamaan penelitian ini menunjukan bahwa persebaran titik data berada diatas dan dibawah angka nol pada sumbu Y dan tidak membentuk pola yang jelas, sehingga model regresi pada penelitian ini lolos uji heteroskedastisitas. 


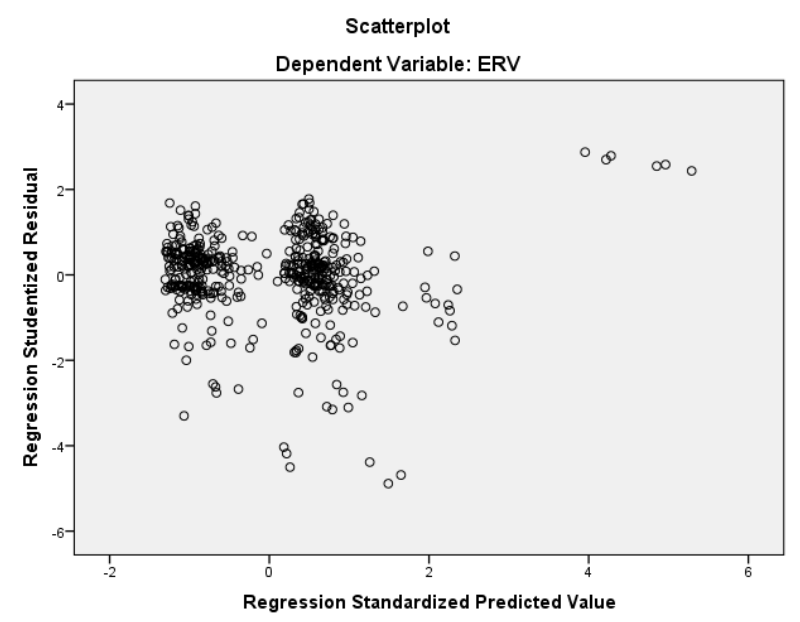

Gambar 3. Hasil Uji Heterokedastisitas

Multikolinearitas dalam penelitian ini dideteksi menggunakan nilai dari Varians Inflating Factor (VIF). Jika nilai VIF dibawah dari 10 menunjukan tidak terdapat korelasi antara variabel bebas dalam model dalam penelitian ini sehingga lolos uji multikolinearitas. Nilai VIF variabel bebas dalam model regresi penelitian ini dibawa 10, menunjukan bahwa tidak terdapat korelasi antara variabel bebas dan dinyatakan lolos uji multikolinearitas.

\section{Hasil Pengujian}

Analisis regresi berganda digunakan untuk menguji hipotesis penelitian ini untuk mengetahui dampak implementasi XBRL terhadap risiko informasi pada perusahaan manufaktur di Indonesia. Berikut ini adalah hasil analisis regresi berganda dari model penelitian ini.

Tabel 6. Hasil Pengujian

\begin{tabular}{ccccc}
\hline Dependen & Independen & Coefficient & Sig. & $\mathbf{R}^{\mathbf{2}}$ \\
\hline \multirow{4}{*}{ ERV } & (Constant) & 0,090 & 0,000 & \\
& XBRL & $-0,002$ & 0,000 & \multirow{2}{*}{0,085} \\
& SIZE & $-0,000$ & 0,000 & \\
\cline { 1 - 3 } & LEV & 0,001 & 0,040 & \\
\cline { 2 - 2 } & Sumber : Data penelitian (2018) &
\end{tabular}

Hasil penelitian menunjukan nilai konstanta pada persamaan regresi berganda dalam penelitian ini sebesar 0,090 dengan nilai sig. sebesar 0.000. Nilai konstanta tersebut memiliki arti ketika variabel XBRL, ERV dan LEV bernilai nol, maka nilai dari variabel ERV sebesar 0,090. Nilai koefisien regresi dari XBRL dalam persamaan ini adalah -0,002 dengan nilai sig. sebesar 0,000 menunjukan XBRL berpengaruh negatif terhadap ERV. Nilai koefisien regresi dari SIZE dalam persamaan regresi ini sebesar $-0,000$ dengan nilai sig. sebesar 0,000 , menunjukan bahwa SIZE berpengaruh negatif terhadap ERV. Nilai koefisien regresi dari LEV dalam persamaan regresi ini sebesar 0,001 dengan nilai sig. sebesar 0,040, menunjukan bahwa LEV berpengaruh positif terhadap ERV. Nilai koefisien determinasi $\left(\mathrm{R}^{2}\right)$ dalam model regresi berganda dalam penelitian ini adalah 0,085 . Nilai tersebut memiliki arti bahwa variabel bebas pada penelitian ini mempengaruhi variabel terikat sebesar $8,5 \%$, sedangkan $91,5 \%$ dipengaruhi oleh variabel bebas lainnya diluar model regresi penelitian ini. 


\section{PEMBAHASAN}

Hipotesis pada penelitian ini adalah perusahaan yang sudah mengadopsi XBRL memiliki tingkat risiko informasi yang rendah. Hipotesis tersebut didukung oleh hasil penelitian. Nilai koefisien regresi dari persamaan dalam penelitian ini memiliki pengaruh negatif signifikan terhadap ERV. Konsisten dengan penelitian Tohang dan Lan (2017), implementasi XBRL mampu mengurangi risiko informasi pada pelaporan keuangan. Hal ini terjadi karena penerapan XBRL dapat meningkatkan kualitas pelaporan sehingga risiko informasi dalam pelaporan laporan keuangan menjadi menurun. Penelitian menunjukan bahwa pelaporan laporan keuangan dengan format XBRL memiliki peningkatan kualitas pada pelaporan keuangan daripada laporan keuangan yang tidak menggunakan format XBRL. Hasil penelitian ini didukung dengan hasil penelitian dari Yoon dkk (2011) dan Enachi (2013) yang menyatakan bahwa adopsi XBRL mampu mengurangi tingkat asimetri informasi pada pelaporan keuangan. Menurunnya tingkat asimetri informasi pelaporan keuangan akan mengurangi terjadinya risiko informasi sehingga stakeholders dapat membuat keputusan yang berkualitas dan sesuai dengan keadaan perusahaan yang sebenarnya. Dalam penelitian Hwang et al. (2008) menyatakan bahwa adopsi XBRL mampu meningkatkan transparansi informasi keuangan. Meningkatnya transparansi informasi keuangan akan mempermudah stakeholders dalam membuat keputusan. Keputusan yang dibuat dengan informasi yang transparan akan terhindar dari kesalahaan pengambilan keputusan sehingga dapat mengurangi terjadinya risiko informasi. Menurut dkk (2017) implementasi XBRL mampu meningkatkan kualitas dari laporan keuangan dengan indikator ketepatan waktu, relevansi, komparabilitas serta efisiensi dari laporan keuangan. Meningkatnya kualitas laporan keuangan akan meminimalisir terjadinya risiko informasi sehingga pengguna laporan keuangan dapat membuat keputusan yang lebih berkualitas.

Implementasi XBRL di Indonesia masih diterapkan pada perusahaan korporasi pada laporan keuangan. Implementasi XBRL di Korea selatan sudah maju dibuktikan dengan penerapan XBRL yang tidak hanya pada perusahaan korporasi tetapi juga pada entitas bisnis kecil dan menengah. Negara-negara yang sudah mengimplementasikan XBRL pada laporan keuuangan masih berfokus pada laporan laba rugi, laporan perubahan ekuitas, laporan posisi keuangan dan laporan arus kas. Implementasi XBRL kedepannya diharapkan dapat diimplementasikan pada catatan atas laporan keuangan, informasi atas tindakan korporasi emiten serta kewajiban keterbukaan informasi dari emiten. Implementasi XBRL diharapkan akan terus berkembang sehingga dapat meningkatkan kualitas laporan keuangan dan pengguna laporan keuangan dapat membuat keputusan yang berkualitas.

\section{KESIMPULAN, KETERBATASAN DAN SARAN}

Dari pembahasan diatas dapat ditarik kesimpulan implementasi XBRL pada pelaporan keuangan mampu mengurangi risiko informasi dalam pelaporan keuangan perusahaan manufaktur yang tercatat dalam BEI tahun 2012-2017.

Secara praktis, hasil penelitian ini menunjukan adanya penurunan risiko informasi pada pelaporan keuangan setelah implementasi XBRL. Menurunnya risiko informasi pada pelaporan keuangan akan meningkatkan kualitas dari pelaporan keuangan perusahaan. Menurunnya risiko informasi ini dapat 
meyakinkan stakeholders atas kualitas pelaporan informasi akuntansi yang telah menggunakan XBRL. Bagi otoritas, hasil penelitian ini dapat digunakan sebagai evaluasi atas manfaat dari implementasi XBRL di Indonesia. Menurunya risiko informasi dalam laporan keuangan meruakan salah satu manfaat dari implementasi XBRL. Saat ini XBRL hanya diterapkan pada laporan laba rugi, laporan perubahan ekuitas laporan posisi keuangan dan laporan arus kas. Kedepannya otoritas dapat lebih yakin dalam mengembangkan implementasi XBRL dengan menerapkan XBRL pada pelaporan informasi keuangan selain laporan keuangan. Implementasi XBRL dapat diterapkan pada catatan atas laporan keuangan, informasi atas tindakan korporasi emiten serta kewajiban keterbukaan informasi dari emiten seperti yang sudah direncanakan sebelumnya oleh BEI.

Dalam bidang akademik, penelitian ini konsisten dengan penelitian Tohang dan Lan (2017) yang menyatakan setelah implementasi XBRL, risiko informasi pada pelaporan keuangan akan menurun. Penelitian ini mendukung penelitian dari Yoon et al. (2011) dan Enachi (2013) yang menyatakan bahwa adopsi XBRL mampu mengurangi tingkat asimetri informasi pada pelaporan keuangan. Penelitian ini juga mendukung penelitian dari Hwang et al. (2008) yang menyatakan bahwa adopsi XBRL mampu meningkatkan transparansi informasi keuangan serta penelitian dari Liu et al. (2017) yang menyatakan bahwa implementasi XBRL mampu meningkatkan kualitas dari laporan keuangan.

Dalam penelitian ini terdapat beberapa keterbatasan yang dapat dipertimbangkan dalam penelitian selanjutnya. ERV merupakan salah satu variabel untuk mengukur risiko informasi. Penelitian selanjutnya dapat menggunakan tolak ukur lain selain ERV yang dapat digunakan untuk menjadi tolak ukur risiko informasi seperti efisiensi informasi. Selain itu dalam penelitian ini hanya meneliti dampak implementasi XBRL pada risiko informasi, untuk penelitian selanjutnya dapat meneliti dampak implementasi XBRL terhadap faktor lain seperti efisiensi pasar setelah implementasi dari XBRL.

\section{DAFTAR PUSTAKA}

BEI. "Xbrl." http://www.idx.co.id/perusahaan-tercatat/xbrl/.

Bushee, Brian J., dan Christopher F. Noe. "Corporate Disclosure Practices, Institutional Investor, and Stock Return Volatility." Journal of Accounting Research 38 (2000): 171-202.

Connelly, Brian L., S. Trevis Certo, R. Duane Ireland, dan Christopher R. Reutzel. "Signaling Theory: A Review and Assessment." Journal of Management 37, no. 1 (2011): 39-67.

Enachi, Mihaela. "Xbrl and Financial Reporting Transparency." Board Research in Accounting, Negotiation, and Distribution 4, no. 1 (2013).

Handayani, Emma, dan Luciana Spica Almilia. "Internet Financial Reporting: Studi Komparasi Perusahaan Manufaktur Yang Terdaftar Di Bursa Efek Indonesia Dan Bursa Efek Malaysia." Jurnal Bisnis dan Ekonomi 20, no. 2 (2013): 10012.

Hwang, Jib Seung, Choon Seong Leem, dan Hyung Joon Moon. "A Study on Relationships among Accounting Transparency, Accounting Information Transparency and Xbrl." In 3rd International Conference on Convergence and Hybrid Information Technology. Busan, South Korea: IEEE, 2008. 
Juliandi, Azuar. Metodologi Penelitian Kuantitatif. Bandung: Citapustaka Media Perintis, 2013.

Kernan, Karen. Xbrl: The Story of Our New Language New York: American Institute of Certified Public Accountants, Inc., 2009.

Kim, Joung W, Jee Hae Lim, dan Won Gyun No. "The Effect of Xbrl Disclosures on Information Environment in the Market: Early Evidence." (2011).

Liu, Chunhui, Xin Robert Luo, dan Fu Lee Wang. "An Empirical Investigation on the Impact of Xbrl Adoption on Information Asymmetry: Evidance from Europe." Decision Support Systems 93 (2017): 42-50.

Santoso, S. Mastering Spss. Jakarta: Kompas Gramedia, 2011.

Sen, Kustav. "Earnings Surprise and Sophiscated Investor Preferences in India." Journal of Contamporary Accounting \& Economics 5, no. 1 (2009).

Tang, Qingliang, Huifa Chen, dan Zhijun Lin. "How to Measure Country-Level Financial Reporting Quality?". Journal of Financial Reporting and Accounting 14, no. 2 (2016): 230-65.

Tohang, Valentina, dan Michellen Lan. "The Impact of Adoption of Xbrl on Information Risk in Representative Countries of Scandinavian Region." Jurnal Keuangan dan Perbankan 21, no. 4 (2017): 515-26.

Widari, Pratiwi Putri, Muhamad Saifi, dan Ferina Nurlaily. "Analisis Internet Financial Reporting (Ifr) (Studi Pada Perusahaan Manufaktur Yang Go Public Di Indonesia, Singapura Dan Malaysia)." Jurnal Administrasi dan Bisnis 56, no. 100-109 (2018).

XBRL. "An Introduction to Xbrl." https://www.xbrl.org/the-standard/what/anintroduction-to-xbrl/.

Yoon, Hyungwook, Hangjung Zo, dan Andrew P. Ciganek. "Does Xbrl Adoption Reduce Information Asymmetry?". Journal of Business Research 64, no. 2 (2011): 157-63. 